\title{
The Cretaceous-Paleogene (K-Pg) Boundary Site at Lechówka-a New Point on the Geoheritage Map of Southeastern Poland
}

\author{
Marcin Machalski ${ }^{1} \cdot$ Katarzyna Stróżyk $^{2}$ (D) $\cdot$ Anna Grabarczyk $^{2}$ \\ Received: 9 November 2018 / Accepted: 26 March 2019/Published online: 22 April 2019 \\ (C) The Author(s) 2019
}

\begin{abstract}
A geological section exposed in an abandoned quarry at Lechówka near Chełm represents the most complete record of the Cretaceous-Paleogene (K-Pg) boundary interval in Poland. Here, a thin clay layer with impact ejecta marks the K-Pg boundary, making Lechówka the single place in Poland with a record of the impact that killed off the dinosaurs. Based on the geoheritage evaluation, the Lechówka outcrop represents a content value of rank intermediate between II and III with the iconographic, symbolic, documental and conceptual contents on the local, regional or even global scale. In spite of the obvious scientific and educational importance of the site, its present state is insufficient to attract 'ordinary' geotourists. In order to ameliorate this situation, transformation of the quarry into an officially protected geosite is called for. Only after a formal, technical and infrastructural upgrade of the Lechówka site, combined with popularisation in the media, tourist guidebooks, websites and natural history museums, will it have a chance to become a widely recognised point on the Cretaceous geoheritage map of southeastern Poland. The most important and already well-known localities on this map are the subterranean chalk mines at Chełm, a series of quarries around the mediaeval town of Kazimierz Dolny and a defunct underground phosphorite mine at Annopol, where there are plans for an educational-geotouristic centre.
\end{abstract}

Keywords Cretaceous-Paleogene $(\mathrm{K}-\mathrm{Pg})$ boundary $\cdot$ Geoconservation $\cdot$ Geotourism $\cdot$ Chełm $\cdot$ Annopol $\cdot$ Kazimierz Dolny

\section{Introduction}

It is now widely accepted that a catastrophic meteorite impact triggered a mass extinction at the end of the Cretaceous (Alvarez et al. 1980; Schulte et al. 2010). The Cretaceous-

This article is part of the Topical Collection on Geoheritage and Conservation: Modern Approaches and Applications Towards the 2030 Agenda, IX ProGEO Symposium, Poland, 25-28th June, 2018

Katarzyna Stróżyk

k.strozyk@student.uw.edu.pl

Marcin Machalski

mach@twarda.pan.pl

Anna Grabarczyk

anna.grabarczyk@student.uw.edu.pl

1 Institute of Paleobiology, Polish Academy of Sciences, ul. Twarda 51/55, 00-818 Warsaw, Poland

2 Faculty of Geology, University of Warsaw, ul. Żwirki i Wigury 93, 02-089 Warsaw, Poland
Paleogene (K-Pg) boundary has been formally defined in a global stratotype section near El Kef (Tunisia), at the base of the so-called boundary clay with an anomalous iridium (Ir) concentration (Molina et al. 2009). This natural stratigraphical boundary has been recognised in almost 100 sites all over the world. The Lechówka outcrop near Chełm, Lublin Upland (Fig. 1), provides the first continuous K-Pg succession in Poland (Figs. 2a and 3) with a distinctive layer of the socalled 'boundary clay' located at the very base of Danian (Paleogene) strata (Racki et al. 2011).

The Lechówka locality is within administrative limits of the Community of Siedliszcze which belongs to the Lublin voivodeship. Despite its obvious educational and scientific values, the site has not been protected and promoted to date, with the exception of a series of popular-science articles (Machalski 2010; Machalski et al. 2010; Machalski and Harasimiuk 2012). Moreover, current scientific values of the Lechówka site are not attractive enough to draw the attention of people who are not strictly involved into the 'Cretaceous World'. Today, this remote and isolated section is rather poorly 

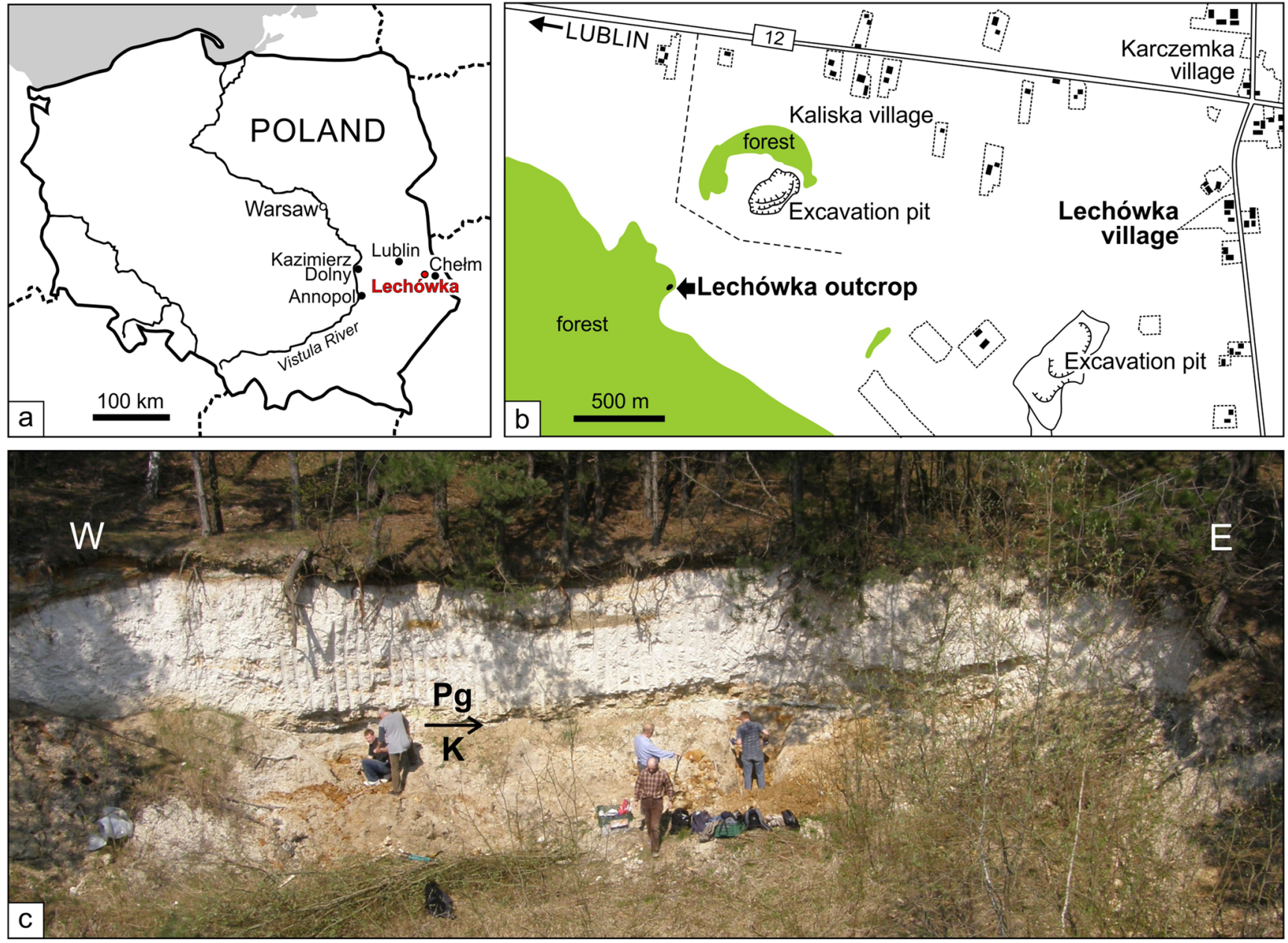

Fig. 1 a, b Location of the Lechówka site in Poland (after Machalski et al. 2016, modified). c General view of the Lechówka outcrop, photo by M. Machalski (2008)

exposed and its state deteriorates year by year because of a lack of proper protection and conservation. It would seem that the sole remedy to ameliorate this unsatisfactory status quo is to create an official geosite at Lechówka and to present it, in a wider perspective, as an important, albeit still underappreciated, point on the map of 'Cretaceous geo-attractions' in the Lublin voivodeship.

The preliminary results of this work were presented as an abstract and poster during the 9th ProGEO Symposium (June 25-28, 2018) at Chęciny, Poland (Stróżyk et al. 2018).

\section{The Geological Description of the Lechówka Section}

The outcrop $\left(51^{\circ} 10^{\prime} 07.0^{\prime \prime} \mathrm{N}, 23^{\circ} 14^{\prime} 24.5^{\prime \prime} \mathrm{E}\right)$ studied is a small, abandoned quarry (Fig. 1c) near the village of Lechówka, south of the main road between Lublin and
Chełm. The quarry is located on a small hilltop, at the edge of a forest, $1.2 \mathrm{~km}$ south of this main road (Fig. 1b).

The sedimentary succession exposed at Lechówka (Figs. 1, 2, and 3) is marine in origin and comprises the most complete record of the Cretaceous-Paleogene boundary in Poland (Racki et al. 2011; Machalski et al. 2016). In terms of lithological development and stratigraphy, it documents striking analogues to the renowned CretaceousPaleogene (K-Pg) boundary succession at Stevns Klint in Denmark (Surlyk et al. 2006). The succession currently exposed at Lechówka is $c .4 \mathrm{~m}$ thick (Fig. 3) and starts with a siliceous limestone with significant amount of sponge spicules (referred to as 'opoka' by Polish geologists; see Pożaryska 1952; Bąk and Szelag 2013; Jurkowska et al. 2019). Locally, there is a brecciated interval within this unit, most probably of tectonic origin (Fig. 3). The siliceous limestone is decalcified at the top and passes upwards into a marly unit. Both these units are late Maastrichtian in age (Racki et al. 2011; Machalski et al. 2016). Higher up in the section, there is a thin layer of dark clay (Figs. 2a and 3 ), composed mainly of smectite-nontronite and 
Fig. 2 a The CretaceousPaleogene (K-Pg) boundary clay layer as exposed at Lechówka (arrowed). b Glauconitic sands and Quaternary deposits at the top of the section. K Cretaceous, $\mathrm{Pg}$ Paleogene, Ol Oligocene, Q Quaternary. Photos by M. Machalski (2008)
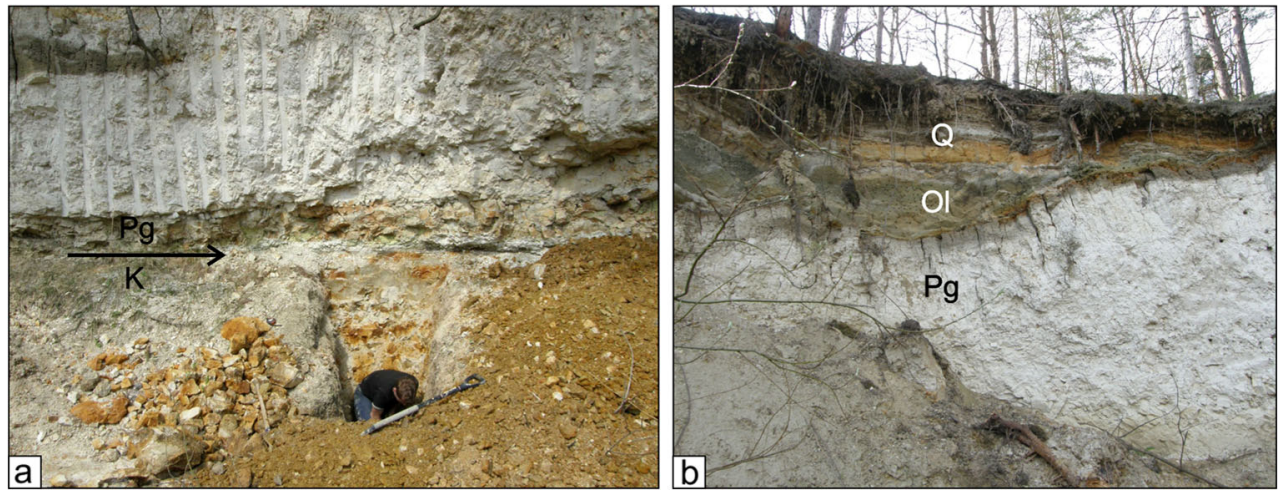

montmorillonite (Szopa et al. 2017) and interpreted as the K-Pg boundary clay following publication of a paper by Racki et al. (2011). Above the boundary clay there is a thin, white, burrowed unit, which is overlain by a glauconite-rich interval (the 'glauconitite' in Fig. 3; see Gazda et al. 1992). Both units are decalcified and overlain by highly porous light opoka with faint traces of rhythmic bedding, which is decalcified as well. Starting with the boundary clay, all successive units of the Lechówka succession are of Danian age (Racki et al. 2011; Machalski et al. 2016).

Locally, the top of the Danian strata is truncated by green glauconite-rich sands with quartz gravel, probably marine in origin (Figs. $2 \mathrm{~b}$ and 3 ). These sands are conventionally referred to Oligocene (Krzowski 2000; see also Pożaryski 1951). A very thin veneer of Quaternary sands and soil forms the top of the section (Fig. 2b).

\section{Scientific and Educational Importance of the Lechówka Section}

In spite of the fact that the Lechówka section is distinctly overprinted by weathering processes, this site offers a unique combination of data on the Maastrichtian-Danian interval. These data have been discussed previously in a series of papers (Racki et al. 2011; Brachaniec et al. 2014; Machalski et al. 2016; Szopa et al. 2017) and can be summarised as follows:

Firstly, an anomalous concentration of Ir (9.6 ppb) and other siderophilic elements such as $\mathrm{Au}, \mathrm{Ni}$ and $\mathrm{Co}$ have been detected in the section. These amounts are consistent with the chondritic composition of the K-Pg impactor (Racki et al. 2011). However, the main Ir anomaly does not occur in the boundary clay itself, but has migrated $\sim 10 \mathrm{~cm}$ downwards in the section (Fig. 3), probably due to the activity of humic acid-rich ground waters
Fig. 3 Lithological and stratigraphical log of the Lechówka section and the iridium content in the section (after Racki et al. 2011, modified)

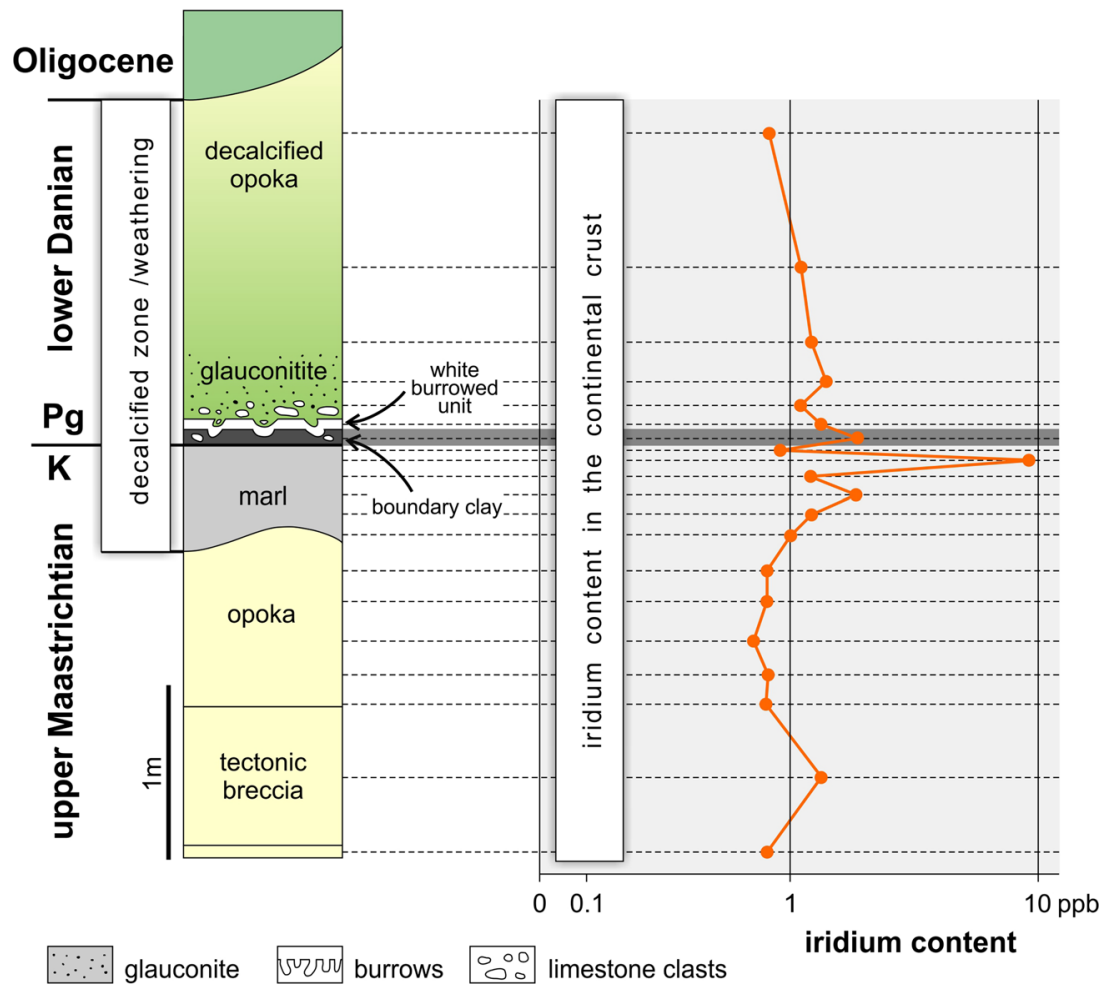


during the Paleogene (Racki et al. 2011). This modified record of the K-Pg boundary event is of key importance for the K-Pg boundary studies worldwide, pointing to a careful reconsideration of the iridium anomaly as a trustworthy marker for studying the extinction patterns across the K-Pg boundary (Racki et al. 2011).

Secondly, the boundary clay at Lechówka contains spherules, similar to the glass spherules known from K-Pg sites elsewhere. The impact origin of spherules from Lechówka has been confirmed by the presence of nickel-rich spinel grains on their surfaces (Brachaniec et al. 2014).

Thirdly, fragments of metallic aggregates, which represent altered ancient iron meteorite have been recorded from the clay. The presence of primary kamacite, taenite and schreibersite enclosed in secondary Ni-rich oxides or hydroxides confirms the extraterrestrial origin of this material (Szopa et al. 2017). However, its composition is inconsistent with the chondritic nature assumed for the main K-Pg impactor and, therefore, the Lechówka palaeometeorite has been interpreted as an independent local meteoritic fall (Szopa et al. 2017).

Fourthly, the upper Maastrichtian part of the section contains abundant macrofossils of latest Cretaceous marine invertebrates, predominantly remains of siliceous sponges and bivalves, including scallops and oysters, but also ammonite moulds (Hoploscaphites constrictus and Baculites sp.). The Lechówka site is among 29 sites known worldwide with a documented record of the stratigraphically youngest ammonites (Landman et al. 2014, 2015). Microfossils are represented by foraminifera and dinoflagellate cysts, which have been used for biostratigraphical correlations and environmental interpretation of the Lechówka section (Machalski et al. 2016).

The geological significance of the Lechówka site is by no means restricted to the K-Pg record. The Danian decalcified opoka, the so-called 'ziemia krzemionkowa', was excavated here during the last century and used in the chemical industry (Tarnas 1963). Therefore, the quarry also represents a mining geoheritage object. The decalcification of the opoka took place in the period between the regression of the Danian sea and the Paleogene (Oligocene?) marine transgression, under conditions of prolonged continental weathering (Pożaryski 1951), possibly related to the Palaeocene-Eocene Thermal Maximum (Racki et al. 2011).

Geological values, providing scientific evidence of the past development of the Earth, affect the educational importance of the Lechówka succession and may be the crucial starting point for demonstration the Earth's history. Currently, the condition of the Lechówka succession makes it essentially educational only for a small group of people (scientists, Earth Science lecturers and students). Improvement of the exposure of the site, its geoconservation and easy accessibility as well as its popularisation will certainly result in increasing its educational values for a wider audience (elementary/primary schools pupils and general tourist).

\section{Geoheritage Map of the Lublin Voivodeship in Cretaceous and Cretaceous-Paleogene Terms}

Several communities located in the Lublin voivodeship offer cultural and natural attractions (Bronisz et al. 2015; Gonera et al. 2015). There are 354 officially registered geosities in this part of Poland, including 97 which are directly connected to Cretaceous and/or Cretaceous-Paleogene rocks (Polish Geological Institute-National Research Institute (n.d.) Central Register of Polish Geosites: http://geoportal.pgi.gov. $\mathrm{pl} /$ portal/page/portal/geostanowiska/projekt). Such a large participation of Cretaceous-related geosities results from the fact that this part of Poland is particularly rich in outcrops of rocks of this age (mainly Campanian and Maastrichtian; see Fig. 1 in Walaszczyk et al. 1999; also Voigt et al. 2008).

Wimbledon et al. (1998) defined geoheritage frameworks for European countries (including Poland), within which selection of sites may occur. Among these frameworks, areas of occurrence of Cretaceous or Cretaceous-Paleogene outcrops within the administrative limits of the Lublin voivodeship were distinguished. These areas belong to following categories: (1) stratigraphical, for Upper Cretaceous transgresive deposits (Polish Uplands including Lublin Upland) and Middle Albian-Upper Cretaceous-lowermost Palaeocene succession (Middle Vistula River section, see below); (2) palaeobiological, for Upper Cretaceous micro- and macrofauna from Middle Vistula River section and (3) historic, for development of geological science (stratigraphy of epicontinental Cretaceous deposits-Central and Southern Poland).

The most attractive 'Cretaceous point' located in close proximity of Lechówka is the town of Chelm (Lublin Upland), $15 \mathrm{~km}$ east of the study area (Fig. 1a). The main geological attraction of Chełm, the city of which is rich in architectural monuments reflecting its multi-cultural history, are subterranean chalk mines, the so-called Chełm Chalk Tunnels (Taurogiński 2010). This is unique (both in Poland and Europe) maze of underground corridors carved in white chalk of early late Maastrichtian (see Dubicka and Peryt 2011). Being an important commodity, the chalk was exploited commercially in the mines beneath the Old Town. The mining activity at Chełm started during the Middle Ages and continued to the end of the nineteenth century, when it came to a halt because of increased risks for houses and residents. The complex systems of tunnels were made accessible to visitors in the 1970s. In total, their length attains $40 \mathrm{~km}, 2 \mathrm{~km}$ of which constitute a touristic route with geological and archaeological exhibits, accessible today (Taurogiński 2010; Gonera et al. 2015).

Further, to the west of the Lechówka site, there is the most important area on the Cretaceous geoheritage map of the Lublin voivodeship (embracing also the easternmost parts of the Świętokrzyskie and Mazowieckie voivodeships). This is the so-called Middle Vistula River section—a series of natural 
and artificial outcrops located along the banks of the River Vistula (Pożaryski 1938; Dubicka and Peryt 2012; Walaszczyk et al. 2016). The section is to form the core of the aspiring 'Geopark Małopolska Gap of the Middle Vistula River' (Harasimiuk et al. 2011).

At the northern end of the Middle Vistula River section, a group of small disused quarries are located in the vicinity of the mediaeval town of Kazimierz Dolny (Fig. 1a). These quarries, at Bochotnica (Fig. 4a), Nasiłów and south of Kazimierz Dolny (the so-called Town Quarry) expose upper Maastrichtian and/or Danian strata, mainly gaizes (carbonate rocks containing significant amount of detrital quartz and glauconite, see Sujkowski 1931) and opokas, which were excavated in the past for building stone and material for river regulation (Bakk and Szelag 2013). The K-Pg boundary interval is accessible at several localities in the area (Pożaryska and Pożaryski 1951; Machalski 1998). The succession (exemplified in Fig. 4a) starts with upper Maastrichtian opoka (Kazimierz Opoka) capped by a limestone layer with numerous crustacean burrows. Higher up, there is a layer of Danian glauconitic sandstone (Greensand) with phosphatic nodules. The greensand passes gradually upwards into gaizes and limestones of the so-called Siwak, of Danian age. The uppermost Maastrichtian and lowermost Danian deposits, including the boundary clay, were originally present in the area, but have subsequently been removed during the early phases of the Danian transgression (Machalski 1998; Machalski and Jagt 2018). In comparison to these three outcrops from the Middle Vistula River section (Kazimierz Dolny, Nasiłów and Bochotnica), the record of the K-Pg interval at Lechówka is more complete (Racki et al. 2011). Both locations - the Middle Vistula River section and Lechówka - complement each other as far as the problematics of the K-Pg interval is concerned. One of the old quarries at Bochotnica with galleries left after underground excavation of opoka, has been protected since 1992 as a documentary site of unanimated nature. It is referred to as the 'Wall of Krystyna and Władysław Pożaryski' (Dybkowska 1993) to commemorate these couple of Polish geoscientists who published several works on the Polish Cretaceous.

Many sections in the Kazimierz Dolny area are still accessible (Walaszczyk et al. 1999). Numerous, often spectacular fossils can be collected there (particularly from the Kazimierz Opoka and Greensand, see Abdel-Gawad 1986; Machalski and Jagt 2018). These facts, in combination with the high, natural landscape and cultural attractions of the Kazimierz Dolny area (Pawłowski 1995; Kowalczyk and Pawłowski 1998; Mezer-Sobotkowska and Sobotkowski 2006), make it one of the key spots on the geotouristic map of Poland.

At the southern end of the Middle Vistula River section, there is the small town of Annopol, situated on the right bank of the River Vistula (Fig. 1a). The Cretaceous marine sands, marls and limestones exposed along the limbs of the Annopol anticline range in age from early Albian to middle Turonian (Machalski and Kennedy 2013; Dubicka and Machalski 2016). Between 1926 and 1970, an Albian phosphorite horizon at Annopol was mined for use in the production of fertilisers; the most intense exploration of phosphorites took place in an underground mine (Makowska and Jędrzejczak 1975).

The long-abandoned mine at Annopol has recently been brought back to the public attention by spectacular finds of Cretaceous marine reptiles, including ichthyosaurs (Machalski et al. 2009; Machalski 2011). Subsequent palaeontological exploration of the Annopol area, inclusive of the mine, by a team led by M. Machalski (Fig. 4b), has yielded extensive collections of Cretaceous fossils, including over 2,000 vertebrate bones and teeth (e.g., Bardet et al. 2016). However, it is not only Cretaceous fossils and deposits that contribute to the value of the Annopol site. Elements of mining infrastructure are still preserved in the mine, including a timber roof and wall support, transportation carts, railway tracks, examples of mining machinery and tools, storehouses and workshops. The Annopol mine is an important

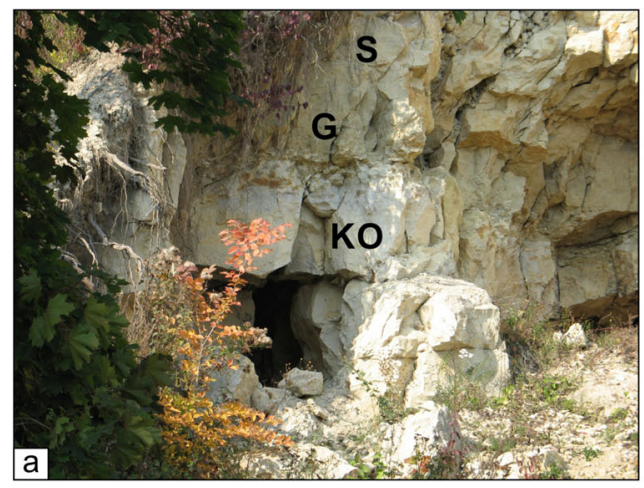

Fig. 4 a General view of the outcrop behind the old watermill at Bochotnica; note: abundant crustacean burrows at the top of the upper Maastrichtian opoka and entrance to gallery left after underground excavation of opoka. b An exposure of the phosphorite horizon in the

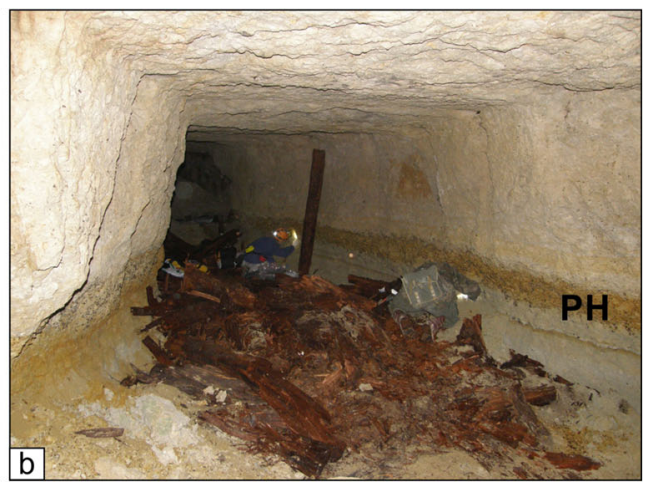

underground mine at Annopol. KO Kazimierz Opoka, G Greensand, S Siwak, PH phosphorite horizon; both photos by M. Machalski (2005 and 2013, respectively) 
reference site for the study of Cretaceous strata, being also of high educational and touristic acclaim in the field of mining history. In appreciation of its unique combination of geoheritage values, an idea to create an educational-geotouristic centre at Annopol was born (Machalski and Liwiński 2018). The geocentre project still awaits implementation, which hopefully would strengthen the otherwise low touristic potential of the Annopol region.

\section{Geoheritage Qualification of the Lechówka Site}

The evaluation and qualification of geosites depend on both the relevance of the meaning attributed to the objects by scientific communities and the public understanding of such meanings related to the social use of the objects (Pena dos Reis and Henriques 2009). The Lechówka site has significant scientific value which attributes the outcrop to the iconographic content. The section contains the record of the K-Pg mass extiction event and its effects - boundary clay and changes in micro- and macrofossils, including the one of the latest ammonite faunas over the world (Landman et al. 2014, 2015). Geochemical and mineralogical features (Brachaniec et al. 2014; Szopa et al. 2017), relevant for understanding changes during the K-Pg interval, correspond to the documental or even conceptual contents, particulary based on regional or global (the last ammonites and "migrated" Ir anomaly) scale geology. Other geoheritage contents can be recognised, namely the symbolic content. Proximity to historical monuments (Chełm and Kazimierz Dolny) contributes to attract people. Following the scientific and cultural heritage characterising the Lechówka section, it has local, regional and global level of relevance grade and also iconographic, documental, symbolic and conceptual content of abstract perceptiveness. Based on this estimation, the Lechówka outcrop represents a content value of rank intermediate between II and III (Fig. 5), following the scheme proposed by Pena dos Reis and Henriques (2009).

\section{Reasons Behind Plans to Conserve the Site at Lechówka}

In view of the above-mentioned unique combination of scientific and educational values, the Lechówka site is frequently visited by scientists and students of geology and geography, although it is totally unknown to general geotourists. So far, being totally unaware of this locality, they have ignored it in view of its remote location, poor accessibility and lack of description in standard touristic publications and websites. To date, the Lechówka site has been presented only in popular-science articles of local circulation (Machalski 2010; Machalski et al. 2010; Machalski and Harasimiuk 2012). There are no other objects of geological interest in the vicinity of the quarry, except for two pits (Fig. 1b) which expose Quaternary fluvio-glacial deposits (sands, gravel and clay deposits with erratic boulders) and also some probably redeposited upper Maastrichtian opoka; one of these pits is officially registered as a geosite (https://geostanowiska.pgi. gov.pl/gsapp_v2/Default.aspx). In this respect, it should be noted that the Community of Siedliszcze, despite its interesting (pre) history (Figiel et al. 2011), has limited touristic potential as is expressed by a low integrated index of tourist attractiveness (ZWAT, see Bronisz et al. 2015). Last,
Fig. 5 The geoheritage estimation of the Lechówka site (green field) based on the system of qualification of the geological heritage contents (Pena dos Reis and Henriques 2009, modified). The iconographic, symbolic, documental and conceptual contents on the local, regional or global scale indicate the rank intermediate between II and III of the site

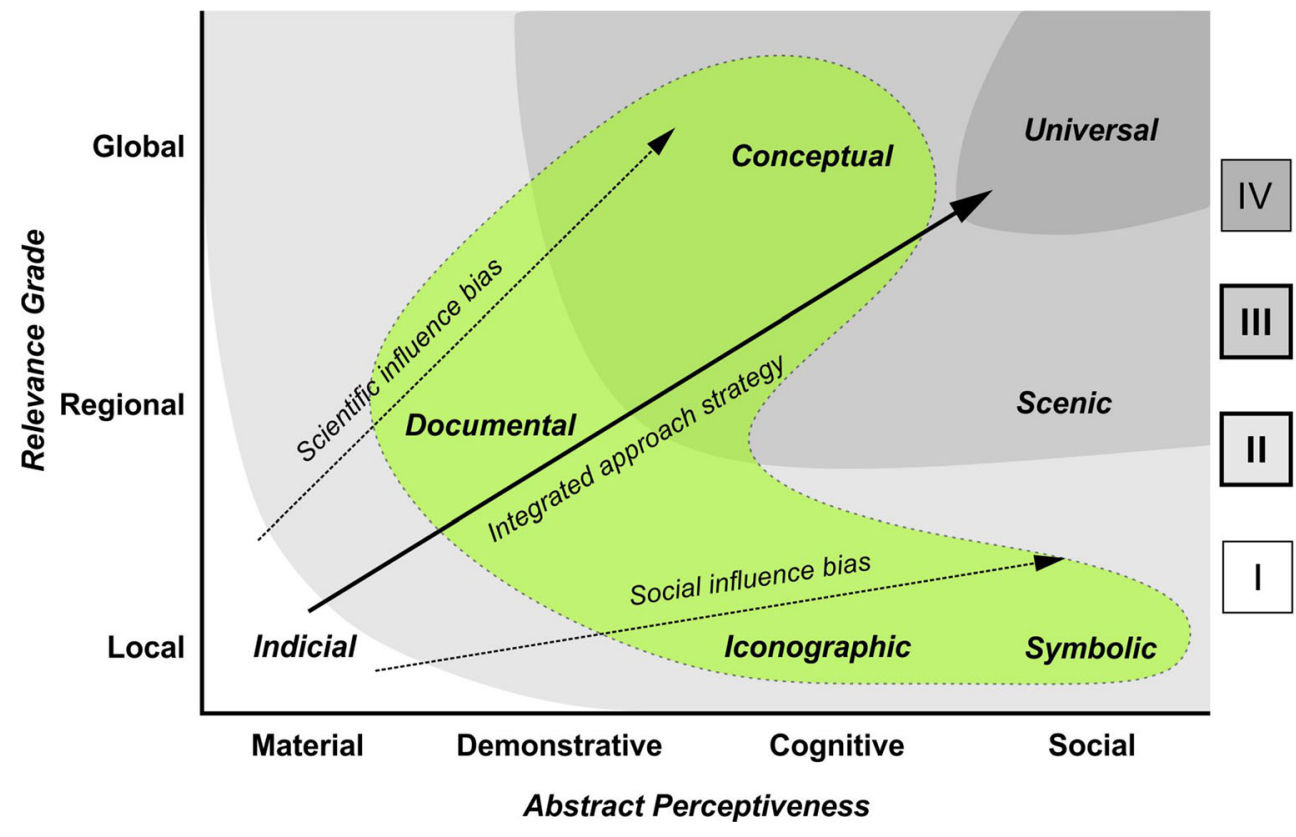


but not the least, the Lechówka site now experiences continuous deterioration as a result of solifluction processes.

In order to assure permanent access by specialists to the Lechówka quarry, as well as to make it 'visible' to ordinary geotourists, the site should be afforded official protection. The following steps are planned to conserve this site: (1) creation of a formal geosite at Lechówka (sensu Alexandrowicz 2003); (2) formal inclusion of the section into the Central Register of Polish Geosites (CRPG), run by the Polish Geological Institute-Polish Research Institute (PIG-PIB); (3) operational protection of the site and appropriate marking of the outcrop in the field by putting up an information board with explanatory notes on its scientific importance; and (4) publication of a popular science description of the site on the website of the Community of Siedliszcze. Technical protection of the quarry faces from landslides and construction of a road to the quarry would be also advisable in order to improve the geotouristic infrastructure of the site.

All these steps cannot be completed without the cooperation of the local community and authorities. The Mayor of the Community of Siedliszcze has declared his help in the implementation of the project and has demonstrated an understanding of the scientific and educational importance of this site. The same positive attitude has also been expressed by the owner of the land on which the outcrop is situated. We believe that the cooperation with local authorities will result in the improvement of the exposure of the Lechówka succession and develops the educational potential of the site.

\section{Concluding Remarks}

The present contribution highligts problems with proper management and popularisation of isolated geoheritage sites. On the one hand, the section exposed at Lechówka yields the most complete record of the Cretaceous-Paleogene (K-Pg) boundary interval in Poland. It is a geological site of high scientific and educational values, being the only place in Poland where there is a record of the impact which killed off the dinosaurs! The assignation of the Lechówka succession to the rank intermediate between II and III of geoheritage evaluation (sensu Pena dos Reis and Henriques 2009) based on iconographic, documental, symbolic and conceptual contents indicate its importance. The geographically nearest outcrops in Europe with a record of K-Pg events are those located at Stevns Klint in Denmark (Surlyk et al. 2006). However, the Lechówka site currently has limited geotouristic potential due to its location in an otherwise geotouristically unattractive area, poor exposure and rather difficult accessibility. In order to ameliorate the situation, transformation of the quarry into an officially protected geosite is needed, as outlined above. Moreover, the site needs support by promulgation in local and regional media, tourist guidebooks, websites and natural history museums (e.g., Muzeum Ziemi Chełmskiej or in JuraPark Bałtów).

Only after a formal, technical and infrastructural upgrade of the Lechówka quarry, combined with an information campaign in the media, will have a chance to become an important point on the Cretaceous geoheritage map of the Lublin voievodeship. The site should be viewed-and popularised-as complementary to the better-known geoheritage gems of southeastern Poland, at Chelm, in the environs of Kazimierz Dolny and possibly at Annopol, if the geocentre concept in the underground mine will eventually be implemented.

Acknowledgements Our thanks go to Mr. Hieronim Zonik, the Mayor of the Community of Siedliszcze, and Mr. Leszek Łukaszewski, who owns the land on which the Lechówka outcrop is situated, for their engagement and help during this project. Mr. Wiesław Liwiński, the former Mayor of the town of Annopol, is acknowledged for his help in field work conducted by the first author at Annopol and his commitment to the geocentre project. Organisers of the IX ProGEO Symposium are acknowledged for the opportunity to present our work there. Aleksandra Hołda-Michalska (Warszawa) is thanked for computer processing of Figs. 1 and 3. John W.M. Jagt (Maastricht) is thanked for linguistic correction of the text. We are also grateful to two anonymous journal referees for their helpful comments.

Open Access This article is distributed under the terms of the Creative Commons Attribution 4.0 International License (http:// creativecommons.org/licenses/by/4.0/), which permits unrestricted use, distribution, and reproduction in any medium, provided you give appropriate credit to the original author(s) and the source, provide a link to the Creative Commons license, and indicate if changes were made.

\section{References}

Abdel-Gawad GI (1986) Maastrichtian non-cephalopod mollusks (Scaphopoda, Gastropoda and Bivalvia) of the Middle Vistula valley, central Poland. Acta Geol Pol 36(1-3):69-224

Alexandrowicz Z (2003) Ochrona dziedzictwa geologicznego Polski w koncepcji europejskiej sieci geostanowisk. Przegl Geol 51(3):224 230 [in Polish with English abstract]

Alvarez LW, Alvarez W, Asaro F, Michel HV (1980) Extraterrestrial cause for the Cretaceous-Tertiary extinction. Science 208(4448): 1095-1108

Bąk B, Szeląg A (2013) Opoki i gezy - zapomniane kopaliny Lubelszczyzny. Górn. Odkrywkowe 54(2):107-116 [in Polish with English abstract]

Bardet N, Fischer V, Machalski M (2016) Large predatory marine reptiles from the Albian-Cenomanian of Annopol, Poland. Geol Mag 153: $1-16$

Brachaniec T, Karwowski Ł, Szopa K (2014) Spherules associated with the Cretaceous-Paleogene boundary in Poland. Acta Geol Pol 62(1): 99-108. https://doi.org/10.2478/agp-2014-0004

Bronisz U, Dymek Z, Jakubowski A, Tucki A (2015) Tourism potential in Lubelskie voivodeship in 2015, Statistical Office in Lublin, Lublin, pp 1-202 [in Polish with English abstract]

Dubicka Z, Machalski M (2016) Foraminiferal record in a condensed marine succession: a case study from the Albian and Cenomanian (mid-Cretaceous) of Annopol, Poland. Geol Mag 154(3):399-418. https://oi.org/10.1017/S0016756816000029 
Dubicka Z, Peryt D (2011) Integrated biostratigraphy of upper Maastrichtian chalk at Chełm (SE Poland). Ann Soc Geol Pol 81(2):185-197

Dubicka Z, Peryt D (2012) Latest Campanian and Maastrichtian palaeoenvironmental changes: implications from an epicontinental sea (SE Poland and western Ukraine). Cretac Res 37:272-284. https://doi.org/10.1016/j.cretres.2012.04.009

Dybkowska M (1993) Geologiczne stanowisko dokumentacyjne ‘Ścianka Krystyny i Władysława Pożaryskich’ w Bochotnicy koło Kazimierza Dolnego. Chrońmy Przyrodę Ojczystą 49(1):30-38 [in Polish]

Figiel G, Kozyrski R, Kuczyńska A (2011) Od prehistorii do współczesności. Odkrywanie lokalnej tożsamości mieszkańców Siedliszcza - monografia historyczna Siedliszcze:1-283 [in Polish]

Gazda L, Harasimiuk M, Krzowski Z (1992) Litogeneza warstw Z glaukonitem w górnej kredzie i paleocenie Pagórów Chełmskich (Wyżyna Lubelska, E Polska). Annales Universitatis Mariae Curie -Skłodowska, Sectio B Geographia, Geologia, Mineralogia et Petrographia 47:1-24 [in Polish]

Gonera H, Niklas G, Rudowicz P, Kłodowski A, Brzeska-Gonera P (2015) Audyt turystyczny województwa lubelskiego. Landbrand, Bellingham, pp 1-225 [in Polish]

Harasimiuk M, Domonik A, Machalski M, Pinińska J, Warowna J, Szymkowiak A (2011) Małopolski Przełom Wisły-projekt geoparku. Przegl Geol 59:405-416 [in Polish with English abstract]

Jurkowska A, Świerczewska-Gładysz E, Bąk M, Kowalik S (2019) (Online 2018) the role of biogenic silica in the formation of Upper Cretaceous pelagic carbonates and its palaeoecological implications. Cretac Res 93:170-187. https://doi.org/10.1016/j.cretres.2018.09. 009

Kowalczyk L, Pawłowski A (1998) Przewodnik po ścieżkach dydaktycznych Kazimierskiego Parku Krajobrazowego, part II, 141 pp. Lublin [in Polish]

Krzowski Z (2000) Glauconite and its geological applications. Wydawnictwo Politechniki Lubelskiej, Lublin, pp 1-139

Landman NH, Goolaerts S, Jagt JW, Jagt-Yazykova EA, Machalski M, Yacobucci MM (2014) Ammonite extinction and nautilid survival at the end of the cretaceous. Geology 42(8):707-710

Landman NH, Goolaerts S, Jagt JWM, Jagt-Yazykova EA, Machalski M (2015) Ammonites on the brink of extinction: diversity, abundance, and ecology of the Order Ammonoidea at the Cretaceous/Paleogene $(\mathrm{K} / \mathrm{Pg})$ boundary. In: Klug C, Korn D, De Baets K, Kruta I, Mapes RH (eds) Ammonoid paleobiology: from macroevolution to paleogeography. Springer, Heidelberg/Berlin, pp 497-553

Machalski M (1998) Granica kreda-trzeciorzęd w przełomie Wisły. Przegl Geol 46:1153-1161 [in Polish with English abstract]

Machalski M (2010) Polski ślad impaktu, który zabił dinozaury. Wiedza i Życie 11:16-17 [in Polish]

Machalski M (2011) Drugie życie annopolskiej kopalni. Rocznik Muzeum Ewolucji 3:20-31 [in Polish]

Machalski M, Harasimiuk M (2012) Ślad kosmicznej katastrofy w Lechówce. Rocznik Muzeum Ewolucji Instytutu Paleobiologii. PAN 4:2-9 [in Polish]

Machalski M, Jagt JWM (2018) A new Danian echinoid assemblage from the Greensand in the Kazimierz Dolny area, central Poland: taxonomy, taphonomy and sedimentological implications. Acta Geol Pol 68:571-596

Machalski M, Kennedy WJ (2013) Oyster-bioimmured ammonites from the Upper Albian of Annopol, Poland: stratigraphic and palaeobiogeographic implications. Acta Geol Pol 63(4):545-554. https://doi.org/10.2478/agp-2013-0024

Machalski M, Liwiński W (2018) Geotourism as a vehicle for geoconservation: the case of an abandoned phosphorite mine at Annopol, Poland. In: Głowniak E, Wasiłowska A, Leonowicz P (eds) Geoheritage and conservation: modern approaches and applications towards the 2030 agenda. 9th ProGEO symposium,
Chęciny, Poland, 25-28th June 2018 Programme and abstract book, faculty of geology. University of Warsaw, Warsaw, pp 50-51

Machalski M, Komorowski A, Harasimiuk M (2009) Nowe perspektywy poszukiwań morskich kręgowców kredowych w nieczynnej kopalni fosforytów w Annopolu nad Wisłą. Przegl Geol 57(8):638-641 [in Polish with English abstract]

Machalski M, Racki G, Koeberl C, Harasimiuk M (2010) Ślad kosmicznej katastrofy. Academia 3(23):32-34 [in Polish]

Machalski M, Vellekoop J, Dubicka Z, Peryt D, Harasimiuk M (2016) Late Maastrichtian cephalopods, dinoflagellate cysts and foraminifera from the Cretaceous-Paleogene succession at Lechówka, southeast Poland: stratigraphic and environmental implications. Cretac Res 57:208-227. https://doi.org/10.1016/j.cretres.2015.08.012

Makowska J, Jędrzejczak M (1975) Rys historyczny badań geologicznych i górnictwa fosforytów w Annopolu. Biul Inst Geol 286:215-235 [in Polish]

Mezer-Sobotkowska K, Sobotkowski Z (2006) Kazimierz Dolny przewodnik turystyczny. Prywatna Agencja Turystyczna, Warszawa, pp 1-119 [in Polish]

Molina E, Alegret L, Arenillas I, Arz JA, Gallala N, Grajales-Nishimura JM, Murillo-Muñetón G, Zaghbib-Turki D (2009) The Global Boundary Stratotype Section and Point for the Base of the Danian Stage (Paleocene, Paleogene, 'Tertiary', Cenozoic): auxiliary sections and correlation. Episodes 32(2):84-95

Pawłowski A (1995) Przewodnik po ścieżkach dydaktycznych Kazimierskiego Parku Krajobrazowego, part I, 1-76 pp. Lublin [in Polish]

Pena dos Reis R, Henriques MH (2009) Approaching an integrated qualification and evaluation system for geological heritage. Geoheritage $1: 1-10$

Polish Geological Institute-National Research Institute (n.d.) Central Register of Polish geosites. https://geostanowiska.pgi.gov.pl/ gsapp_v2/Default.aspx. Accessed 2 November 2018

Pożaryska K (1952) Zagadnienia sedymentologiczne górnego mastrychtu i danu okolic Puław. Biul Państw Inst Geol 81:1-104 [in Polish]

Pożaryska K, Pożaryski W (1951) Przewodnik geologiczny po Kazimierzu i okolicy. Wydawnictwo Muzeum Ziemi, Warszawa, pp 1-101 [in Polish]

Pożaryski W (1938) Stratygrafia senonu w przełomie Wisły między Rachowem i Puławami. Biul Państw Inst Geol 6:1-94

Pożaryski W (1951) Odwapnione utwory kredowe na północnowschodnim przedpolu Gór Świętokrzyskich. Biul Państw Inst Geol 75:1-70 [in Polish]

Racki G, Machalski M, Koeberl C, Harasimiuk M (2011) (online 2010). The weathering-modified iridium record of a new CretaceousPalaeogene site at Lechówka near Chełm, SE Poland, and its palaeobiologic implications. Acta Palaeontol Pol 56(1):205-215. https://doi.org/10.4202/app.2010.0062

Schulte P, Alegret L, Arenillas I, Arz JA, Barton PJ, Bown PR, Bralower TJ, Christeson GL, Claeys P, Cockell CS, Collins GS, Deutsch A, Goldin TJ, Goto K, Grajales-Nishimura JM, Grieve RAF, Gulick SPS, Johnson KR, Kiessling W, Koeberl C, Kring DA, MacLeod KG, Matsui T, Melosh J, Montanari A, Morgan JV, Neal CR, Nichols DJ, Norris RD, Pierazzo E, Ravizza G, Rebolledo-Vieyra M, Reimold WU, Robin E, Salge T, Speijer RP, Sweet AR, UrrutiaFucugauchi J, Vajda V, Whalen MT, Willumsen PS (2010) The Chicxulub asteroid impact and mass extinction at the CretaceousPaleogene boundary. Science 327:1214-1218

Stróżyk K, Grabarczyk A, Machalski M (2018) Reasons behind plans to conserve the Cretaceous-Paleogene Boundary site at Lechówka, southeast Poland. In: Głowniak E, Wasiłowska A, Leonowicz P (eds) Geoheritage and conservation: modern approaches and applications towards the 2030 agenda. 9th ProGEO symposium, Checciny, Poland, 25-28th June 2018, Programme and abstract book. Faculty of Geology, University of Warsaw, pp 169-170 
Sujkowski Z (1931) Petrografia kredy Polski. Kreda z głębokiego wiercenia $\mathrm{w}$ Lublinie $\mathrm{w}$ porównaniu $\mathrm{z}$ kredą niektórych innych obszarów Polski. Sprawozdania Państwowego Instytutu Geologicznego 6:485-628 [in Polish]

Surlyk F, Damholt T, Bjerager M (2006) Stevns Klint, Denmark: uppermost Maastrichtian chalk, Cretaceous-Tertiary boundary, and lower Danian bryozoan mound complex. Bull Geol Soc Den 54:1-48

Szopa K, Brachaniec T, Karwowski Ł, Krzykawski T (2017) Remnants of altered meteorite in the Cretaceous-Paleogene clay boundary in Poland. Meteorit Planet Sci 52(4):612-622. https://doi.org/10.1111/ maps. 12815

Tarnas W (1963) Ziemia krzemionkowa w województwie lubelskim. Przegl Geol 11(1):21-26 [in Polish]

Taurogiński W (2010) The chalk-written route: a guide around Chełm Country, the city of Chełm and Trebiszów. Wydawnictwo Chełm, Lubelska, pp 1-60
Voigt S, Wagreich M, Surlyk F, Walaszczyk I, Uličný D, Čech S, Voigt T, Wiese F, Wilmsen M, Niebuhr B, Reich M, Funk H, Michalik J, Jagt JWM, Felder PJ, Schulp AS (2008) Cretaceous. In: McCann T (ed) The geology of Central Europe - Mesozoic and Cenozoic, vol 6(2). Geological Society of London, London, pp 923-997

Walaszczyk I, Cieśliński S, Sylwestrzak H (1999) Selected geosities of Cretaceous deposits in Central and Eastern Poland. Pol Geol Inst Spec Pap 2:71-76

Walaszczyk I, Dubicka Z, Olszewska-Nejbert D, Remin Z (2016) Integrated biostratigraphy of the Santonian through Maastrichtian (Upper Cretaceous) of extra-Carpathian Poland. Acta Geol Pol 66(3):321-358. https://doi.org/10.1515/agp-2016-0016

Wimbledon WAP, Ivchenko A, Gerasimenko N, Alexandrowicz Z et al (1998) A first attempt at a geosites framework for Europe - an IUGS initiative to support recognition of world heritage and European geodiversity. Geol Balc 28(3-4):5-32 